\title{
An interactive key to the Chrysochromulina species (Haptophyta) described in the literature
}

\author{
Marie-Josèphe Chrétiennot-Dinet', Nicolas Desreumaux', Régine Vignes-Lebbe² \\ I Sorbonne Universités, UPMC Univ Paris 06, UMS 2348, Observatoire Océanologique, F-66650 Banyuls/ \\ Mer, France 2 Sorbonne Universités, UPMC Univ Paris 06, UMR 7207 (MNHN, UPMC, CNRS) et UMR \\ 7205 (MNHN, UPMC, CNRS, EPHE), CP48, 57 rue Cuvier, 75231 Paris cedex 05, France
}

Corresponding author: Nicolas Desreumaux (nicolas.desreumaux@obs-banyuls.fr)

Academic editor: L. Penev | Received 13 September 2013 | Accepted 6 February 2014 | Published 13 February 2014

Citation: Chrétiennot-Dinet M-J, Desreumaux N, Vignes-Lebbe R (2014) An interactive key to the Chrysochromulina species (Haptophyta) described in the literature. PhytoKeys 34: 47-60. doi: 10.3897/phytokeys.34.6242

\begin{abstract}
We present a general overview of features and technical specifications of an original interactive key web application for the identification of Chrysochromulina species. The list of species, originally described as belonging in the genus Chrysochromulina, is given and recent taxonomic changes in species and genera of the order Prymnesiales are provided. We briefly discuss the interest of such a key for the identification of phytoplanktonic species.
\end{abstract}

\section{Keywords}

Interactive key, identification tool, XPER ${ }^{2}$, web application, morphology, description protocol, phytoplankton, Chrysochromulina

\section{Introduction}

The genus Chrysochromulina, erected by Lackey (1939) is an important component of the marine and brackish phytoplankton although the type species occured in fresh water. Electron microscopy (EM) has been a key tool for a specific identification and Mary Parke \& Irene Manton were pioneers in reviewing the type species (Parke et al. 1962) and describing more than ten species between 1955 and 1966. They remained for many years the specialists of the genus until Barry Leadbeater added some more new species so that almost half the number of species known today were described by 1974 . With the extent of TEM (Transmission Electron Microscopy) or SEM (Scanning Electron Microscopy) 
studies, the genus appeared worldwide distributed and some species were found to produce massive blooms, some of which were eventually toxic (Moestrup 1994). The 1988 bloom of Chrysochromulina polylepis Manton \& Parke (Dahl et al.1989) was the first event of toxic bloom causing important economic impact, raising a considerable interest of the scientific community especially in Scandinavia. Two $\mathrm{PhD}$ thesis were submitted (Jensen 1998, Eikrem 1999 ) with an illustrated key for identification of species of this genus, based on morphological characters (Eikrem et al. 1998). With the 21th century molecular biology introduced changes in the delineation of classes and orders and the genus Chrysochromulina was considered as polyphyletic (Edvardsen et al. 2000).

The class name Haptophyceae was first used by Christensen in 1962 but Hibberd introduced the typified class name Prymnesiophyceae (Hibberd 1976), both names being considered as valid. More recently Silva et al. (2007) advise the use of the name Coccolithophyceae for this class, considering that the class name Coccolithophyceae Rothmaler 1951 had priority over Haptophyceae and Prymnesiophyceae. However this class name remains a matter of debate and therefore is not mentionned in the title.

Within the class, the genus Chrysochromulina was for a long time placed in the order Prymnesiales and the family Prymnesiaceae. However, from DNA phylogenies and morphological comparisons, Edvardsen et al. (2011) reviewed the taxonomy of the Prymnesiales. They emended the Family Prymnesiaceae W. Conrad ex O.C. Schmidt emend. Edvardsen, Eikrem \& Medlin, (Edvardsen et al. 2011), placing five species of Chrysochromulina (C. palpebralis, C. polylepis, C. kappa, C. chiton and C. minor) in the genus Prymnesium, and five other species (C. brevifila, C. ericina, C. fragaria, $C$. herdlensis \& C. hirta) in the new genus Haptolina Edvardsen \& Eikrem (Edvardsen et al. 2011). An unnamed species, cited as Chrysochromulina sp4 (Eikrem \& Edvardsen, 1999), is considered as the type species of the new genus Pseudohaptolina Edvardsen \& Eikrem. They give a formal description of this species as P. arctica Edvardsen \& Eikrem (Edvardsen et al. 2011). Because of these changes, the family Chrysochromulinaceae Edvardsen, Eikrem \& Medlin is now restricted to the unique genus Chrysochromulina with the remaining species, all being saddle-shaped cells (Edvardsen et al. 2011).

As we are dealing here with an identification key, we have taken into consideration all species originally described as Chrysochromulina in the literature (or moved to this genus as for Chrysocampanula spinifera (Fournier) by Pienaar and Norris in 1979) but modifications of their taxonomic status are mentioned in the species descriptions. References are restricted to papers giving the original description of a species or an emended description.

\section{Project description}

\section{Taxonomic coverage}

The key covers 58 species originally described as Chrysochromulina. References for publications dealing with their description and occurrence are given. A detailed description 
is provided and illustrations of a whole cell as well as for the different scale types, in some cases from unpublished material seen in SEM, are included. It is noticeable that two of them have different morphologies described as "forma": C. polylepis, now Prymnesium polylepis, "authentic" or "alternate" (Edvardsen and Paasche 1992, Edvardsen et al. 1996, Edvardsen and Medlin 1998); C. palpebralis f. palpebralis or C. palpebralis $\mathrm{f}$. bisquamata (Seoane et al. 2009). As mentioned before, an additional species, referred to as Chrysochromulina sp. 4 (Eikrem and Edvardsen 1999) is now considered as the type species of the new genus Pseudohaptolina (Edvardsen et al. 2011). The terminal taxa of the key are 63 because all morphological forms are treated separately. A few of them (freshwater species) are poorly described (C. inornamenta Wujek \& Gardiner, $C$. chiton var. minuta and C. papillata Gao, Tseng \& Guo, C. laurentiana Kling) but still may be identified through this key.

List of the terminal taxa included in the current version of the database (last update, July 20I3)

Chrysochromulina acantha Leadbeater \& Manton (1971); Chrysochromulina adriatica Leadbeater (1974); Chrysochromulina arenghotii Jensen \& Moestrup (1999); Chrysochromulina alifera Parke \& Manton (1956) in Parke et al. (1956); Chrysochromulina apheles Moestrup \& Thomsen (1986); Chrysochromulina bergenensis Leadbeater (1972); Chrysochromulina birgeri Hällfors \& Niemi (1974); Chrysochromulina brachycylindra Hällfors \& Thomsen (1985); Chrysochromulina breviflum Parke \& Manton (1955) in Parke et al. (1955), now Haptolina brevifila (Parke \& Manton) Edvardsen \& Eikrem 2011; Chrysochromulina breviturrita Nicholls (1978); Chrysochromulina camella Leadbeater \& Manton (1969); Chrysochromulina campanulifera Manton \& Leadbeater (1974); Chrysochromulina chiton Parke \& Manton (1958) in Parke et al. (1958), now Prymnesium chiton (Parke \& Manton) Edvardsen, Eikrem \& Probert (2011); Chrysochromulina chiton var. minuta Gao, Tseng \& Guo (1993); Chrysochromulina cyathophora Thomsen (1979); Chrysochromulina cymbium Leadbeater \& Manton (1969); Chrysochromulina discophora Manton (1983); Chrysochromulina elegans Estep et al. (1984); Chrysochromulina ephippium Parke \& Manton (1956) in Parke et al. (1956); Chrysochromulina ericina Parke \& Manton (1956) in Parke et al. (1956), now Haptolina ericina (Parke \& Manton) Edvardsen \& Eikrem 2011; Chrysochromulina fragaria Eikrem \& Edvardsen (1999), now Haptolina fragaria (Eikrem \& Edvardsen) Edvardsen \& Eikrem 2011; Chrysochromulina fragilis Leadbeater (1972); Chrysochromulina herdlensis Leadbeater (1972), now Haptolina herdlensis (B. Leadbeater) Edvardsen \& Eikrem 2011; Chrysochromulina hirta Manton (1978b), now Haptolina hirta (Manton) Edvardsen \& Eikrem 2011; Chrysochromulina inornamenta Wujek \& Gardiner (1985); Chrysochromulina kappa Parke \& Manton (1955) in Parke et al. (1955), now Prymnesium kappa (Parke \& Manton) Edvardsen, Eikrem \& Probert, 2011; Chrysochromulina lanceolata Chrétiennot-Dinet, Nezan \& Puigserver (2003) in Puigserver et al. (2003); Chrysochromulina latilepis Manton (1982); Chrys- 
ochromulina laurentiana Kling H.J. (1981); Chrysochromulina leadbeateri Eikrem \& Throndsen (1998); Chrysochromulina limonia Jensen \& Moestrup (1998); Chrysochromulina mactra Manton (1972); Chrysochromulina mantoniae Leadbeater (1972) ; Chrysochromulina megacylindra Leadbeater (1972); Chrysochromulina microcylindra Leadbeater (1972); Chrysochromulina minor Parke \& Manton (1955) in Parke et al. (1955), now Prymnesium minus (Parke \& Manton) Edvardsen, Eikrem \& Probert, 2011; Chrysochromulina novae-zelandiae Moestrup (1979); Chrysochromulina orbiculata Rouchijajnen (1972); Chrysochromulina pachycylindra Manton \& Oates (1981) in Manton et al. (1981); Chrysochromulina palpebralis Seoane, Eikrem, Edvardsen \& Pienaar (2009), now Prymnesium palpebrale (Seoane, Eikrem, Edvardsen \& Pienaar) Edvardsen, Eikrem \& Probert, 2011; Chrysochromulina papillata Gao, Tseng \& Guo (1993); Chrysochromulina parkae Green \& Leadbeater, (1972); Chrysochromulina parva Lackey (1939); Chrysochromulina pelagica Estep, Davis, Hargraves \& Sieburth (1984); Chrysochromulina planisquama Hu \& Tseng (2005) in Hu et al. (2005); Chrysochromulina polylepis Manton \& Parke (1962), now Prymnesium polylepis (Manton \& Parke) Edvardsen, Eikrem \& Probert, 2011; Chrysochromulina pontica Rouchijajnen (1966); Chrysochromulina pringsheimii Parke \& Manton (1962); Chrysochromulina pseudolanceolata Chrétiennot-Dinet \& Puigserver (2003) in Puigserver et al. (2003); Chrysochromulina pyramidosa Thomsen (1977); Chrysochromulina quadrikonta Kawachi \& Inouye (1993); Chrysochromulina rotalis Eikrem \& Throndsen (1999); Chrysochromulina scutellum Eikrem \& Moestrup (1998); Chrysochromulina simplex Estep, Davis, Hargraves \& Sieburth (1984) emend. Birkhead and Pienaar (1995); Chrysochromulina spinifera (Fournier 1971) Pienaar \& Norris (1979) back to Chrysocampanula spinifera Fournier 1971 (see Edvarsen et al. 2011); Chrysochromulina strobilus Parke and Manton (1959) in Parke et al. (1959); Chrysochromulina tenuispina Manton (1978a); Chrysochromulina tenuisquama Estep, Davis, Hargraves \& Sieburt (1984); Chrysochromulina throndsenii Eikrem (1996); Chrysochromulina vexillifera Manton \& Oates (1983).

\section{Characters used in the key}

The key matrix is based on one ecological character (habitat) and 19 morphological descriptors seen in light or electron microscopy, under live conditions or after fixation for EM observations. They range from cell shape to scale ornamentation. Details of scales can be obtained by specific techniques with TEM, such as direct preparations (Moestrup and Thomsen 1980, Jensen 1998) and cultures are generally needed. Although rarely used, SEM can also provide interesting results with natural samples (Puigserver et al. 2003). For fragile cells, $3 \mathrm{~mL}$ of sample are fixed with $50 \mu \mathrm{L}$ of a 1:1 Lugol/Glutaraldehyde $(25 \%)$ solution, centrifuged on a Thermanox cell culture coverslip coated with poly-L-lysine $(0.1 \%)$ for a better adherence of cells, critical point dried and then examined with a field emission scanning electron microscope. 


\section{List of descriptors used in the key:}

HABITAT: marine, brackish, freshwater

SHAPE: spherical-subspherical, elongate to round, lanceolate, saddle-shaped

CELL LENGTH, CELL WIDTH: min. and max. sizes are given for each form or species.

FLAGELLA: Two flagella are present and may be equal or sub-equal, in that case the length of the longer and shorter flagellum are given.

HAPTONEMA BEHAVIOR: coiling, rarely coiling, non coiling.

HAPTONEMA LENGTH: min. and max. size (in some cases, the haptonema may be very long)

NUMBER OF SCALE TYPES: in some cases, scales may be displayed in several layers and show up to four different types but there is always a layer of plate scales as cell covering.

SCALE APPENDICES: besides plate scales, a number of different appendices can be observed : spine, cylinder or another typical ornamentation.

PLATE SCALE LENGTH AND WIDTH: min. and max. sizes are given for all plate scales.

\section{Software used}

The interactive key is developed using Xper2 version 2.2 software. It is free software available with multilingual interface and compatible with different OS (Windows, $\mathrm{MacOS}$ and Linux) under a creative commons license (BY-CC-ND). You can download it on http://www.infosyslab.fr and find on this website a complete documentation with technical details, user manual and knowledge bases.

Xper2 offers an editor to structure and analyse descriptive data and an interface for interactive free access key (Ung et al. 2010). Keys of various taxonomic groups are already available with Xper2 (Kerner et al. 2011) (Mathieu et al. 2012) (Thomas and De Franceschi 2013).

We installed the interactive key on a web server with Apache2, choosing the English interface. This content is under a creative commons license (BY-CC-ND), except when a special information is attached to images.

\section{The knowledge base}

Xper2 manages structured descriptive data: all the terminal taxa of the key are described using the same terms (descriptor and character states labels), and so the taxa can be compared automatically.

Figure 1 presents the comparison of the two forms attributed to Prymnesium palpebrale (previously Chrysochromulina palpebralis). The different colors allow to point 


\begin{tabular}{|c|c|c|c|c|}
\hline (4) Comparison & & & & \begin{tabular}{|l|l|l|}
0 & 回 $x$ \\
\end{tabular} \\
\hline Legend & & & & \\
\hline Discrimination & & & & \\
\hline Partial discrimination & & & & \\
\hline No discrimination & & & & \\
\hline & $\begin{array}{c}\text { Chrysochromulina palpebralis } \mathrm{f} . \\
\text { bisquamata }=\text { Prymnesium palpebrale }\end{array}$ & $\begin{array}{c}\text { Chrysochromulina palpebralis } \mathbf{f} \\
\text { palpebralis = Prymnesium palpebrale }\end{array}$ & UNION & INTERSECTION \\
\hline Habitat & Marine & Marine & Marine & Marine \\
\hline Shape & elongate to round & elongate to round & elongate to round & elongate to round \\
\hline Cell length & Min:8.0 Max:13.0 & Min:8.0 Max:13.0 & $\begin{array}{l}{[8.0 ; 13.0] \&} \\
{[8.0 ; 13.0]}\end{array}$ & {$[8.0 ; 13.0]$} \\
\hline Cell width & Min:6.0 Max:9.0 & Min:6.0 Max:9.0 & $\begin{array}{l}{[6.0 ; 9.0] \&} \\
{[6.0 ; 9.0]}\end{array}$ & {$[6.0 ; 9.0]$} \\
\hline Flagella & Equal & Equal & Equal & Equal \\
\hline Flagella length & Min:20.0 Max:27.0 & Min:20.0 Max:27.0 & $\begin{array}{l}{[20.0 ; 27.0] \&} \\
{[20.0 ; 27.0]}\end{array}$ & {$[20.0 ; 27.0]$} \\
\hline Haptonema behavior & non coiling & non coling & non coiling & non coiling \\
\hline Haptonema length & Min:7.0 Max:15.0 & Min:7.0 Max:15.0 & \begin{tabular}{|l}
{$[7.0 ; 15.0] \&$} \\
{$[7.0 ; 15.0]$}
\end{tabular} & {$[7.0 ; 15.0]$} \\
\hline $\begin{array}{l}\text { Number of scale } \\
\text { types }\end{array}$ & 2 & 3 & 2,3 & \\
\hline Scale appendices & Absent & Present & Absent, Present & \\
\hline Scale appendices type & not applicable & Spine; Other & Spine, Other & \\
\hline Spine length & not applicable & Min:0.5 Max:1.0 & {$[0.5 ; 1.0]$} & {$[0.5 ; 1.0]$} \\
\hline $\begin{array}{l}\text { Other appendice } \\
\text { characteristics }\end{array}$ & not applicable & eye-lash projections & \begin{tabular}{|l|} 
eye-lash \\
projections
\end{tabular} & \\
\hline Plate scale sizes & Min:0.39 Max:1.25 & Min:0.54 Max:0.93 & {$[0.39 ; 1.25]$} & {$[0.54 ; 0.93]$} \\
\hline $\begin{array}{l}\text { Specific scale } \\
\text { ornamentation }\end{array}$ & yes & yes & yes & yes \\
\hline \multicolumn{5}{|c|}{\begin{tabular}{|l|l|} 
& $\|$ \\
\end{tabular}} \\
\hline & Save & Print Close & & \\
\hline
\end{tabular}

Figure I. Comparison of the two forms of Prymnesium palpebrale. The two forms are very similar and differ only on scales and appendices.

easily where the descriptions are distinct, overlap, or are the same. Here the two forms differ on scale type number and appendices.

In the same way the comparison of the five species (Haptolina brevifila, H. ericina, $H$. fragaria, $H$. herdlensis and $H$. hirta) previously known as Chrysochromulina but attributed in 2011 in the new genus Haptolina (Edvardsen et al. 2011) shows that these species share few attributes used in the key (Figure 2).

\section{The online interactive key}

Our key of the Chrysochromulina species is a free access key accessible at http://www. obs-banyuls.fr/chrysochromulina. It offers an interactive and flexible way to identify these phytoplanktonic species. 


\begin{tabular}{|c|c|c|c|c|c|c|c|}
\hline \multicolumn{7}{|l|}{ Comparison } & \begin{tabular}{|l|l|l|}
0 & a & $x$ \\
\end{tabular} \\
\hline \multicolumn{8}{|l|}{ Legend } \\
\hline \multicolumn{8}{|l|}{ Discrimination } \\
\hline \multicolumn{8}{|c|}{ Partial discrimination } \\
\hline \multicolumn{8}{|c|}{ No discrimination } \\
\hline & $\begin{array}{c}\text { Chrysochromulina } \\
\text { brevifilum }= \\
\text { Haptolina brevifila }\end{array}$ & $\begin{array}{c}\text { Chrysochromulina } \\
\text { ericina = Haptolina } \\
\text { ericina }\end{array}$ & $\begin{array}{c}\text { Chrysochromulina } \\
\text { fragaria }=\text { Haptolina } \\
\text { fragaria } \\
\end{array}$ & $\begin{array}{c}\text { Chrysochromulina } \\
\text { herdlensis }= \\
\text { Haptolina herdlensis }\end{array}$ & $\begin{array}{c}\begin{array}{c}\text { Chrysochromulina } \\
\text { hirta }=\text { Haptolina } \\
\text { hirta }\end{array} \\
\end{array}$ & union & INTERSECTION \\
\hline Habitat & Marine; Brackish & Marine; Brackish & Marine & Marine; Brackish & Marine; Brackish & Marine, Brackish & Marine \\
\hline Shape & spherical-subspherical & elongate to round & spherical-subspherical & elongate to round & spherical-subspherical & $\begin{array}{l}\text { spherical-subspherical, } \\
\text { elongate to round }\end{array}$ & \\
\hline Cell length & Min-4.0 Max:10.0 & Min-5.0 Max:12.0 & Min:4.0 Max:8.0 & Min:3.0 Max:4.0 & Min:6.0 Max:12.0 & {$[3.0 ; 12.0]$} & \\
\hline Cell width & Min:4.0 Max:10.0 & Min:4.0 Max:10.0 & Min:4.0 Max:8.0 & Min:3.0 Max:4.0 & Min:6.0 Max:12.0 & {$[3.0 ; 12.0]$} & \\
\hline Flagella & Equal & Equal & Equal & Equal & Equal & Equal & Equal \\
\hline Flagella length & Min: 11.0 Max:20.0 & Min:10.0 Max:30.0 & Min:10.0 Max:16.0 & Mean:35.0 & Min:11.0 Max:20.0 & $\begin{array}{l}{[10.0 ; 20.0] \&} \\
{[10.0 ; 20.0]} \\
\end{array}$ & {$[11.0 ; 16.0]$} \\
\hline $\begin{array}{l}\begin{array}{l}\text { Haptonema } \\
\text { behavior }\end{array} \\
\end{array}$ & rarely coiling & coiling & rarely colling & coling & coling & rarely colling, colling & \\
\hline $\begin{array}{l}\text { Haptonema } \\
\text { length }\end{array}$ & Min:3.0 Max:14.0 & Min:20.0 Max: 60.0 & Min:3.0 Max:8.0 & Mean: 15.0 & Min: 30.0 Max: 50.0 & $\begin{array}{l}{[3.0 ; 14.0] \&} \\
{[20.0 ; 60.0]}\end{array}$ & \\
\hline \begin{tabular}{|l|}
$\begin{array}{l}\text { Number of } \\
\text { scale types }\end{array}$ \\
\end{tabular} & 3 & 2 & 2 & 3 & 3 & 3,2 & \\
\hline $\begin{array}{l}\text { Scale } \\
\text { appendices }\end{array}$ & Present & Present & Absent & Absent & Present & Present, Absent & \\
\hline \begin{tabular}{|l} 
Scale \\
appendices type
\end{tabular} & Spine & Spine & not applicable & not applicable & Spine & Spine & \\
\hline Spine length & Min:0.63 Max:0.72 & Min:9.0 Max:15.0 & not applicable & not applicable & Minn. .0 Max:30.0 & $\begin{array}{l}{[0.63 ; 0.72] \&} \\
{[5.0 ; 15.0]}\end{array}$ & \\
\hline Plate scale sizes & Min:0.53 Max:1.02 & Min: 0.5 Max: 0.6 & Min: 0.35 Max:0.8 & Min:0.4 Max:2.6 & $\begin{array}{l}\text { UmethLower: } 1.3 \\
\text { UmethUpper:1.6 }\end{array}$ & {$[0.35 ; 2.6]$} & \\
\hline $\begin{array}{l}\text { Specific scale } \\
\text { ormamentation }\end{array}$ & no & no & no & no & no & no & no \\
\hline \multicolumn{8}{|c|}{ 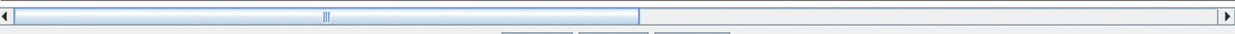 } \\
\hline & & & Save & int Close & & & \\
\hline
\end{tabular}

Figure 2. Comparison of the five species of the new genus Haptolina. The column «intersection» on the right side gives the values shared by the five species.

A classical polytomous key consists of a series of questions (characters), each one offering alternative statements (Hagedorn et al. 2010). A free access key is a more flexible identification key: the sequence of choices is defined by the user preventing these of characters difficult or impossible to observe.

Figure 3 shows the screen during an identification process. Each item (terminal taxon of the key) is documented by a text including nomenclatural data, type locality, literature references and morphological data, and is illustrated by several images. Descriptors and character states are also documented and illustrated.

At each step, the user may ask the software to find the best characters to distinguish the possible taxa. Three different measures are proposed Xper, Jaccard, and Sokal \& Michener (as "Best descriptors" in the select box). For each pair of remaining taxa, each coefficient measurement compares the possible states and the final result is the sum for all the pairs. Xper coefficient checks only if there is no overlap (it means the two taxa may be completely distinct on this character) and so the measure for one pair of taxa is 0 (if overlapping) and 1 (if no overlapping). Jaccard coefficient was initially developed to compare sets of binary characters; here the states are considered as the binary characters and the 


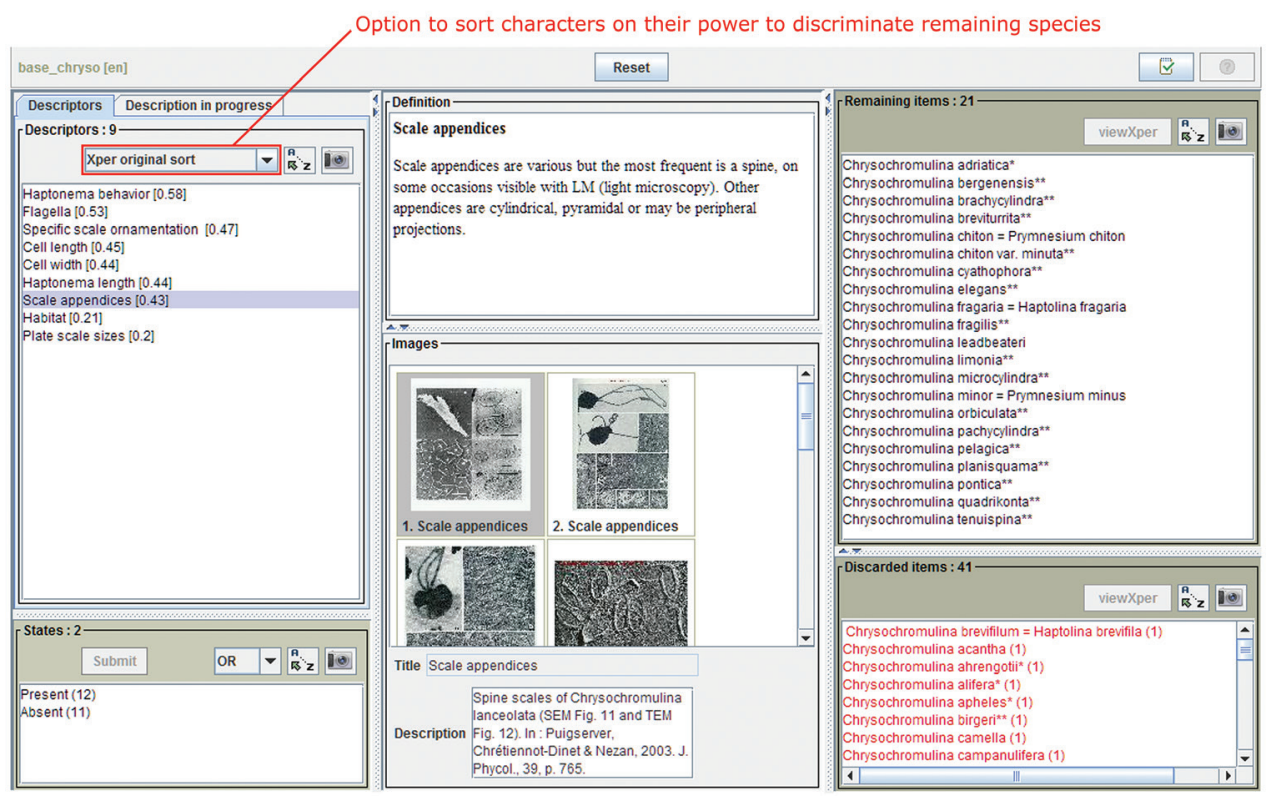

Figure 3. Example of screen of the free access key. On the left the user chooses descriptor and states with the help of the additional ressources, text and images in the center of the screen. On the right the lists of remaining and eliminated species.

comparison takes into account the ratio between the number of states possible for only one taxon of the pair and the number of states possible for at least one taxon of the pair. In the Sokal \& Michener coefficient, the states which are not possible for the two taxa are also taken into account. The three measures are described in Burguière et al. (2013).

\section{Conclusions}

Identification of Chrysochromulina species has long been reserved to specialists as it is a major difficulty for most phytoplanktonologists. The cells are very small, often overlooked or placed as "unidentified" species in field studies. Cultures and specific preparations are generally needed to get relevant information on morphological features. A key for identification of Scandinavian species (Eikrem et al. 1998), based on TEM observations of cultures has only been published in PhD Theses (Jensen 1998 and Eikrem 1999). A list of species as part of toxic haptophytes was published by Moestrup \& Thomsen in a manual on harmful marine microalgae (Moestrup and Thomsen 2004). However original descriptions are not always available for researchers. In this interactive key, all species found in the literature are treated and information necessary for their identification is provided. This key is a very powerful tool for a taxonomic work on the genus and is therefore strongly recommended, especially for phytoplanktonologists working on nanoflagellates. The content of the key was carefully checked 


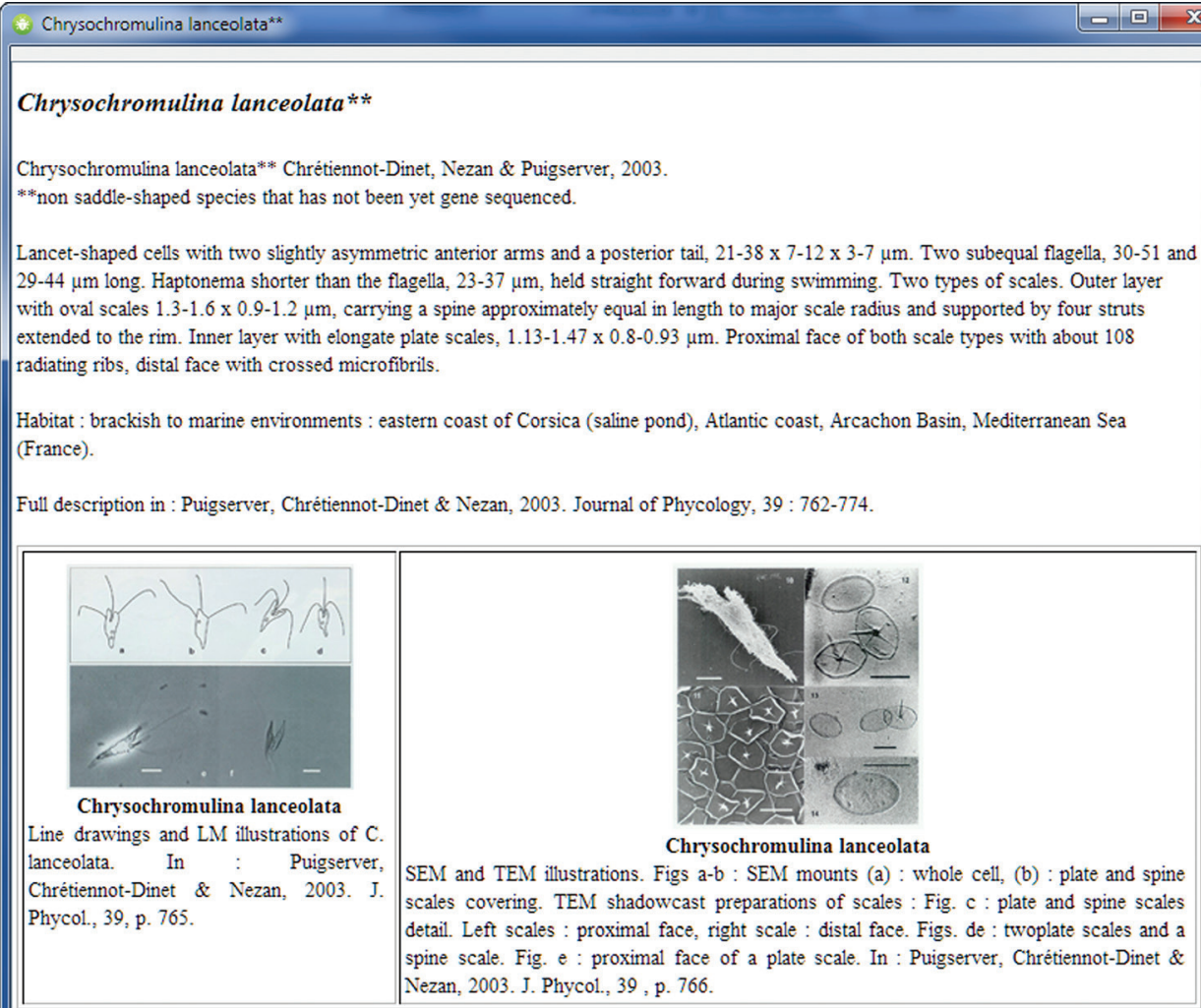

- Habitat : Marine ; Brackish

- Shape : lanceolate

- Cell length : Min:21.0 Max:38.0

- Cell width : Min:3.0 Max:7.0

- Flagella : Sub-equal

- Longer Flagellum length : Min:30.0 Max:51.0

- Shorter Flagellum length : Min:29.0 Max:44.0

- Haptonema behavior : rarely coiling

- Haptonema length : Min:23.0 Max:37.0

Figure 4. Example of descriptors (in red) that allow differentiation between C. lanceolata and a specimen under identification.

and tested with information on species characteristics found in the Scandinavian key (Jensen 1998, Eikrem 1999) and unpublished data obtained by one author (M-J C-D). Among all descriptors used in this key, those concerning the scale description are most important and the mean number of required characters to identify a species is 4.3. SEM preparations from field samples seem promising for identification of these species (Puigserver et al. 2003 and unpublished illustrations shown in the key). The choice of characters introduced without order is also an important advantage as compared to a classical key: characteristics of a typical scale may be enough for a specific identification. 


\section{Acknowledgements}

We thank Valérie Domien for creating the home page and for drawing illustrations of C. brachycylindra and Jennifer Guarini for corresponding with editors about copyright. We also thank the reviewers for their very constructive comments.

\section{References}

Birkhead M, Pienaar RN (1995) The taxonomy and ultrastructure of Chrysochromulina simplex (Prymnesiophyceae). Phycologia 34(2): 145-156. doi: 10.2216/i0031-8884-34-2-145.1

Burguiere T, Causse F, Ung V, Vignes-Lebbe R (2013) IKey+: A New Single-Access Key Generation Web Service. Systematic Biology 62(1): 157-161. doi: 10.1093/sysbio/sys069

Dahl E, Lindhal O, Paasche E, Throndsen J (1989) The Chrysochromulina polylepis bloom in Scandinavian waters during spring 1988. In: Cosper EM, Bricelj VM, Carpenter EJ (Eds) Novel Phytoplankton blooms. Causes and impacts of recurrent brown tides and other unusual blooms. Springer-Verlag, Berlin, 383-405. doi: 10.1029/CE035p0383

Edvardsen B, Eikrem W, Green JC, Andersen RA, Moon-Van der Staay SY, Medlin L (2000) Phylogenetic reconstructions of the Haptophyta inferred from the $18 \mathrm{~S}$ ribosomal DNA sequences and available morphological data. Phycologia 39(1): 19-35. doi: 10.2216/i00318884-39-1-19.1

Edvardsen B, Eikrem W, Throndsen J, Saez AG, Probert I, Medlin LK (2011) Ribosomal DNA phylogenies and a morphological revision provide the basis for a revised taxonomy of the Prymnesiales (Haptophyta). European Journal of Phycology 46(3): 202-228. doi: $10.1080 / 09670262.2011 .594095$

Edvardsen B, Eikrem W, Vaulot D, Paasche E (1996) Comparison between authentic and alternate Chrysochromulina polylepis : morphology, growth, toxicity and ploidy level. In : Yasumoto T, Oshima Y, Fukuyo Y (Eds) Harmful and Toxic Algal Blooms. Intergovernmental Oceanographic Commission of UNESCO, Tokyo, 231-234.

Edvardsen B, Medlin LK (1998) Genetic analyses of authentic and alternate forms of Chrysochromulina polylepis (Haptophyta). Phycologia 37(4): 275-283. doi: 10.2216/i00318884-37-4-275.1

Edvardsen B, Paasche E (1992) Two motile stages of Chrysochromulina polylepis (Prymnesiophyceae): morphology, growth, and toxicity. Journal of Phycology 28(1): 104-114. doi: 10.1111/j.0022-3646.1992.00104.x

Eikrem W (1996) Chrysochromulina throndsenii sp. nov. (Prymnesiophyceae). Description of a new haptophyte flagellate from Norwegian waters. Phycologia 35(3): 377-380. doi: 10.2216/i0031-8884-35-5-377.1

Eikrem W, Edvardsen B (1999) Chrysochromulina fragaria sp. nov. (Prymnesiophyceae), a new haptophyte flagellate from Norwegian waters. Phycologia 38(2): 149-155. doi: 10.2216/ i0031-8884-38-2-149.1

Eikrem W (1999) The Class Prymnesiophyceae (Haptophyta) in Scandinavian waters. Aspects of taxonomy, abundance, diversity and nutrition. PhD Thesis, University of Oslo, Norway. 
Eikrem W, Jensen MØ, Moestrup Ø, Throndsen J (1998) An illustrated key to the unmineralised prymnesiophyceaen flagellates of Scandinavian marine waters with special reference to the genus Chrysochromulina. In: Jensen M Ø (1998) The Genus Chrysochromulina (Prymnesiophyceae) in Scandinavian waters - Diversity, Abundance and Ecology. PhD Thesis, V: 1-36. University of Copenhagen, Denmark.

Eikrem W, Moestrup Ø (1998) Structural analysis of the flagellar apparatus and the scaly periplast in Chrysochromulina scutellum sp. nov. (Prymnesiophyceae, Haptophyta), from the Skagerrak and the Baltic. Phycologia 37(2): 132-153. doi: 10.2216/i0031-8884-37-2-132.1

Eikrem W, Throndsen J (1998) Morphology of Chrysochromulina leadbeateri (Prymnesiophyceae) from northern Norway. Phycologia 37(4): 292-299. doi: 10.2216/i0031-8884-374-292.1

Eikrem W, Throndsen J (1999) The morphology of Chrysochromulina rotalis sp. nov. (Prymnesiophyceae, Haptophyta), isolated from the Skagerrak. Sarsia 84(5-6): 445-449.

Estep KW, Davis PG, Hargraves PE, Sieburth J McN (1984) Chloroplast containing microflagellates in natural populations of North Atlantic nanoplankton, their identification and distribution; including a description of five new species of Chrysochromulina (Prymnesiophyceae). Protistologica 20(4): 613-634.

Fournier RO (1971) Chrysocampanula spinifera gen. et sp. nov., a new marine haptophyte from the Bay of Chaleurs, Quebec. Phycologia 10(1): 89-92. doi: 10.2216/i0031-8884-10-1-89.1

Gao Y, Tseng CK, Guo Y (1993) Some new species of nannoplankton in Jiaozhou Bay, Shandong, China. Chinese Journal of Oceanology and Limnology 11(2): 108-114 + 2 Pl.

Green JC, Leadbeater BSC (1972) Chrysochromulina parkae sp. nov. (Haptophyceae) a new species recorded from S.W. England and Norway. Journal of the marine biological Association of the U.K. 52(2): 469-474. doi: 10.1017/S002531540001883X

Hagedorn G, Rambold G, Martellos S (2010) Types of identification keys. In: Nimis PL, Vignes-Lebbe R (Eds) Tools for Identifying Biodiversity: Progress and Problems. Edizioni Università di Trieste, 59-64.

Hällfors G, Niemi A (1974) A Chrysochromulina (Haptophyceae) bloom under the ice in the Tvärminne archipelago, southern coast of Finland. Memoranda Societatis pro Fauna et Flora Fennica 50: 89-104.

Hällfors S, Thomsen HA (1985) Chrysochromulina brachycylindra sp. nov. (Prymnesiophyceae) from Finnish coastal waters. Nordic Journal of Botany 5(5): 499-504. doi: 10.1111/ j.1756-1051.1985.tb01685.x

Hu XY, Yin MY, Tseng CK (2005) Morphology of Chrysochromulina planisquama sp. nov. (Haptophyta, Prymnesiophyceae) isolated from Jiaozhou Bay, China. Botanica Marina 48(1): 52-57.

Jensen MØ (1998) The Genus Chrysochromulina (Prymnesiophyceae) in Scandinavian waters - Diversity, Abundance and Ecology. PhD Thesis, University of Copenhagen, Denmark.

Jensen MØ (1998) A new method for fixation of unmineralized haptophytes for TEM (whole mount) investigations. Journal of Phycology 34(3): 558-560. doi: 10.1046/j.15298817.1998.340558.x

Jensen MØ, Moestrup Ø (1998) Observations on Chrysochromulina limonia sp. nov. (Prymnesiophyceae, Haptophyta), a new species ressembling Chrysochromulina polylepis. In: Jensen MØ 
(1998) The Genus Chrysochromulina (Prymnesiophyceae) in Scandinavian waters - Diversity, Abundance and Ecology. PhD Thesis, III: 1-17. University of Copenhagen, Denmark. Jensen MØ, Moestrup Ø (1999) Ultrastructure of Chrysochromulina ahrengotii sp. nov. (Prymnesiophyceae), a new saddle-shaped species of Chrysochromulina from Danish coastal waters. Phycologia 38(3): 195-207. doi: 10.2216/i0031-8884-38-3-195.1

Kawachi M, Inouye I (1993) Chrysochromulina quadrikonta sp. nov., a quadriflagellate member of the genus Chrysochromulina (Prymnesiophyceae = Haptophyceae). Japanese Journal of Phycology (Sôrui) 41: 221-230.

Kerner A, Debrenne F, Vignes-Lebbe R (2011) Cambrian archaeocyathan metazoans: revision of morphological characters and standardization of genus descriptions to establish an online identification tool. Zookeys 150: 381-395. doi: 10.3897/zookeys.150.1566

Kling HJ (1981) Chrysochromulina laurentiana: an electron microscopic study of a new species of Prymnesiophyceae from Canadian Shield lakes. Nordic Journal of Botany 1(4): 551-555. doi: 10.1111/j.1756-1051.1981.tb00722.x

Lackey JB (1939) Notes on plankton flagellates from the Scioto River - Lloydia 2: 128-143.

Leadbeater BSC (1972) Fine structural observations on six species of Chrysochromulina (Haptophyceae) from Norway, with preliminary observations on scale production in C. microcylindra. Sarsia 49(1): 65-80.

Leadbeater BSC (1974) Ultrastructural observations on nanoplankton collected from the coast of Jugoslavia and the Bay of Algiers Journal of the marine biological Association of the U.K. 54(1): 179-196.

Leadbeater BSC, Manton I (1969) Chrysochromulina camella sp. nov. and Chrysochromulina cymbium sp. nov., two new relatives of $C$. strobilus Parke and Manton. Archiv für Mikrobiologie 68(1): 116-132. doi: 10.1007/BF00413872

Leadbeater BSC, Manton I (1971) Fine structure and light microscopy of a new species of Chrysochromulina (C. acantha). Archiv für Mikrobiologie 78(1): 58-69. doi: 10.1007/BF00409088

Manton I (1972) Preliminary observations on Chrysochromulina mactra sp. nov. British Phycological Journal 7(1): 21-35. doi: 10.1080/00071617200650031

Manton I (1978a) Chrysochromulina tenuispina sp. nov. from arctic Canada. British Phycological Journal 13(3): 227-234. doi: 10.1080/00071617800650271

Manton I (1978b) Chrysochromulina hirta sp. nov., a widely distributed species with unusual spines. British Phycological Journal 13(1): 3-14. doi: 10.1080/00071617800650021

Manton I (1982) Chrysochromulina latilepis sp. nov. (Prymnesiophyceae = Haptophyceae) from the Galapagos Islands, with preliminary comparisons with relevant taxa from South Africa. Botanica Marina 25(4): 163-169. doi: 10.1515/botm.1982.25.4.163

Manton I (1983) Nanoplankton from the Galapagos Islands : Chrysochromulina discophora sp. nov. (Haptophyceae $=$ Prymnesiophyceae), another species with exceptionally large scales. Botanica Marina 26(1): 15-22. doi: 10.1515/botm.1983.26.1.15

Manton I, Leadbeater BSC (1974) Fine structural observations on six species of Chrysochromulina from wild Danish marine nanoplankton, including a description of C. campanulifera sp. nov. and a preliminary summary of the nanoplankton as a whole. Det Kongelige Danske Videnskabernes Selskab Biologiske Skrifter 20(5): 1-26. 
Manton I, Oates K (1983) Nanoplankton from the Galapagos Islands : Chrysochromulina vexillifera sp. nov. (Haptophyceae $=$ Prymnesiophyceae), a species with semivestigial body spines. Botanica Marina 26(11): 517-525. doi: 10.1515/botm.1983.26.11.517

Manton I, Oates K, Course PA (1981) Cylinder-scales in marine flagellates from the genus Chrysochromulina $($ Haptophyceae $=$ Prymnesiophyceae) with a description of $C$. pachycylindra sp. nov. Journal of the marine biological Association of the U.K. 61(1): 17-26. doi: $10.1017 /$ S0025315400045884

Manton I, Parke M (1962) Preliminary observations on scales and their mode of origin in Chrysochromulina polylepis sp. nov. Journal of the marine biological Association of the U.K. 42(3): 565-578. doi: 10.1017/S0025315400054266

Mathieu B, Cêtre-Sossah C, Garros C, Chavernac D, Balenghien T, Carpenter S, SetierRio M-L, Vignes-Lebbe R, Ung V, Candolfi E, Delécolle J-C (2012) Development and validation of IIKC: an interactive identification key for Culicoides (Diptera: Ceratopogonidae) females from the Western Palaearctic region. Parasites \& Vectors 5: 137. doi: $10.1186 / 1756-3305-5-137$

Moestrup $\varnothing$ (1979) Identification by electron microscopy of marine nanoplankton from New Zealand, including the description of four new species. New Zealand Journal of Botany 17: 61-95. doi: 10.1080/0028825X.1979.10425161

Moestrup Ø (1994) Economic aspects: "blooms", nuisance species, and toxins. In: Green JC, Leadbeater BSC (Eds) The Haptophyte Algae, Systematics Association, Special Volume. Clarendon Press, Oxford. 51: 265-285.

Moestrup Ø, Thomsen HA (1980) Preparation of shadow-cast whole mounts. In: Gantt E (Ed) Handbook of phycological methods. Developmental and cytological methods. Cambridge University Press, 385-390.

Moestrup Ø, Thomsen HA (1986) Ultrastructure and reconstruction of the flagellar apparatus in Chrysochromulina apheles sp. nov. (Prymnesiophyceae= Haptophyceae). Canadian Journal of Botany 64(3): 593-610. doi: 10.1139/b86-077

Moestrup $\varnothing$, Thomsen HA (2004) Taxonomy of toxic haptophytes (prymnesiophytes). In: Hallegraeff GM, Anderson DM, Cembella AD (Eds) Manual on harmful marine microalgae. UNESCO Publishing, Paris, France, 433-463.

Nicholls KH (1978) Chrysochromulina breviturrita sp. nov., a new freshwater member of the Prymnesiophyceae. Journal of Phycology 14(4): 499-505. doi: 10.1111/j.15298817.1978.tb02476.x

Parke M, Lund JWG, Manton I (1962) Observations on the biology and fine structure of the type species of Chrysochromulina (C. parva Lackey) in the English Lake District. Archiv für Mikrobiologie 42(4): 333-352. doi: 10.1007/BF00409070

Parke M, Manton I (1962) Studies on marine flagellates. VI. Chrysochromulina pringsheimii sp. nov. Journal of the marine biological Association of the U.K. 42(2): 391-404. doi: $10.1017 /$ S0025315400001387

Parke M, Manton I, Clarke B (1955) Studies on marine flagellates. II. Three new species of Chrysochromulina. Journal of the marine biological Association of the U.K. 34(3): 579-609. doi: $10.1017 /$ S0025315400008833 
Parke M, Manton I, Clarke B (1956) Studies on marine flagellates. III. Three further species of Chrysochromulina. Journal of the marine biological Association of the U.K. 35(2): 387-414. doi: 10.1017/S0025315400010225

Parke M, Manton I, Clarke B (1958) Studies on marine flagellates. IV. Morphology and microanatomy of a new species of Chrysochromulina. Journal of the marine biological Association of the U.K. 37(1): 209-228. doi: 10.1017/S0025315400014910

Parke M, Manton I, Clarke B (1959) Studies on marine flagellates. V. Morphology and microanatomy of Chrysochromulina strobilus sp. nov. Journal of the marine biological Association of the U.K. 38(1): 169-188. doi: 10.1017/S0025315400015678

Pienaar RN, Norris R (1979) The ultrastructure of the flagellate Chrysochromulina spinifera (Fournier) comb. Nov. (Prymnesiophyceae) with special reference to scale production. Phycologia 18(2):99-108. doi: 10.2216/i0031-8884-18-2-99.1

Puigserver M, Chrétiennot-Dinet MJ, Nezan E (2003) Some Prymnesiaceae (Haptophyta, Prymnesiophyceae) from the Mediterranean Sea, with the description of two new species: Chrysochromulina lanceolata sp. nov. and C. pseudolanceolata sp. nov. Journal of Phycology 39(4): 762-774. doi: 10.1046/j.1529-8817.2003.02120.x

Rouchijajnen MI (1966) Duae species novae e Chrysophytis mobilibus maris nigri. Novitates Systematicae Plantorum 3: 10-15.

Rouchijajnen MI (1972) Flagellatae marium australium nova. Novitates systematicae plantorum 9: 11-17.

Seoane S, Eikrem W, Pienaar R, Edvardsen B (2009) Chrysochromulina palpebralis sp. nov. (Prymnesiophyceae): a haptophyte possessing two alternative morphologies. Phycologia 48(3): 165-176. doi: 10.2216/08-63.1

Silva PC, Throndsen J, Eikrem W (2007) Revisiting the nomenclature of haptophytes. Phycologia 46(4): 471-475. doi: 10.2216/07-22.1

Thomas R, De Franceschi D (2013) Palm stem anatomy and computer-aided identification: The Coryphoideae (Arecaceae). American Journal of Botany 100(2): 289-313. doi: 10.3732/ajb.1200242

Thomsen HA (1977) Chrysochromulina pyramidosa sp. nov. (Prymnesiophyceae) from Danish coastal waters. Botaniska Notiser 130: 147-153.

Thomsen HA (1979) Chrysochromulina cyathophora (Prymnesiophyceae), a new species from Danish coastal waters. Botaniska Notiser 132: 71-76.

Ung V, Dubus G, Zaragüeta-Bagils R, Vignes-Lebbe R (2010) Xper²: introducing e-Taxonomy. Bioinformatics 26(5): 703-704. doi: 10.1093/bioinformatics/btp715

Wujek DA, Gardiner WE (1985) Chrysophyceae (Mallomonadaceae) from Florida. II. New species of Paraphysomonas and the prymnesiophyte Chrysochromulina. Florida Scientist 48(1): 59-63. 